How to cite this article:

Syed Nong, S. N. A., Mustaffa, A., Ismail, N., Salleh, K., Yusof, M. N., \& Awang, M.B. (2020). Protection of children beyond control in the IR 4.0 era: The role of international conventions. UUM Journal of Legal Studies, 11(2), 77-96. https:// doi.org/10.32890/uumjls.11.2.2020.8695

\title{
PROTECTION OF CHILDREN BEYOND CONTROL IN THE IR 4.0 ERA: THE ROLE OF INTERNATIONAL CONVENTIONS
}

\author{
${ }^{1}$ Shariffah Nuridah Aishah Syed Nong, ${ }^{2}$ Aminuddin Mustaffa, \\ ${ }^{3}$ Nazli Ismail, ${ }^{4}$ Kamaliah Salleh, ${ }^{5}$ M. Naziree Yusof \& \\ ${ }^{6}$ M. Badrol Awang \\ ${ }^{1-6}$ Faculty of Law and International Relations, \\ Universiti Sultan Zainal Abidin
}

1Corresponding author: aishah@unisza.edu.my

Received: 10/2/2020 Revised: 7/6/2020 Accepted: 14/6/2020 Published: 31/7/2020

\begin{abstract}
The Fourth Industrial Revolution (IR 4.0) has undeniably affected the way of life of people, including children. The rapid development of the Internet and digital technology coupled with unlimited, easy, and fast access make children highly susceptible to harm arising from the use of social media, films, or games. This situation may expose children who are beyond control to immense threats due to poor relationships with their parents and family members. Beyond control children may be found anywhere. They are the children who frequently disobey their parents' orders and are notorious as "status offenders" at the international level. Despite the noncriminal nature of their misbehaviour, children who are beyond control are often treated like criminals through court proceedings and detention orders. Meanwhile, numerous international conventions and guidelines have been signed including the United Nations Convention on the Rights of the Child to protect the welfare of all children. However, to what extent do these conventions protect
\end{abstract}


the children who are beyond control? What are the principles applicable to these children, and how are they protected? Thus, this study was conducted to analyse the extent of protection provided by international conventions for the rights of children who are beyond control and to suggest suitable programmes for the implementation of the international principles in the IR 4.0 era. This qualitative study employed the library research method for data collection. It analysed numerous documents including international conventions, statutes, books, journals, conference proceedings, and reports. This study found that the international conventions provide protection to the children who are beyond control through several principles including the best interest of the child, family and government responsibilities, institutional placement, prevention of delinquency, and diversion. These principles may be applied through diversionary programmes including counselling, family group conference, family and school programme, and mentoring programme.

Keywords: Status offence, children beyond control, industrial revolution 4.0, international conventions.

\section{INTRODUCTION}

The world is presently undergoing technology transformation, which will change how humans live, work, and communicate. StudyMalaysia.com (2018) estimates that starting from the year 2025, 90 per cent of the world's population will have access to the Internet and own a smartphone. The Fourth Industrial Revolution (IR 4.0), which is supported by the latest technologies, including Internet of Things (IoT), cloud computing, and cognitive computing, enable speedy interaction unrestricted by borders. OTTO Motors (2020) states that the revolution introduces new terms such as Big Data (a collection of data from traditional and digital sources), Smart Factory (smooth connection of production steps), and Cyber Physical Systems (integration of computation, networking, and physical processes). Artificial intelligence or intelligence established by machines is currently dominating the lives of humans whereby vehicles can be driven virtually without human control, payment for goods or hailing cabs can be executed remotely in a speedy manner, and video games can be played without human players (Schwab, 2016). 
IR 4.0 has affected the way of life of children as well, as they are seen to spend more time on digital devices. UNICEF (2017) discovered that children constitute one out of three Internet users in the world. The rapid development of the Internet and digital technology makes them more susceptible to online harm or risk especially through the use of social media, films, or games due to the unlimited, easy, and fast access. Further, UNICEF has identified three categories of online risk affecting children, namely, content risk, contact risk, and conduct risk. "Content risk" denotes immoral or negative online contents such as sexual, pornographic, and violent images, while "contact risk" refers to unsafe communication such as communication with individuals who persuade them to join dangerous or unhealthy acts and "conduct risk" signifies children who commit negative behaviours including posting sexual images and writing hateful materials. These situations may expose children, particularly those who are beyond parental control, to immense threats due to the poor relationships with their parents and families. The negative effects of digital technology on children who are beyond control is indirectly corroborated by findings from UNICEF that the use of the Internet may magnify the situation in children who suffer from depression, commit truancy, or have issues at home.

Beyond control behaviour, which involves disobedience or rebelliousness towards parents' orders, has occurred for centuries whereby it was regarded as a serious offence which must be punished. One of the world's oldest written laws, the Code of Hammurabi governing Babylon between 1792 and 1750 B.C., contained specific laws on children who disobeyed their parents' orders (Regoli \& Hewitt, 2006). The code provided for cutting off hands in the event that a boy hit his father and cutting off the tongue in the event that an adopted child claimed that the adoptive parent was not his or her parent. Beyond control behaviour continued during the Greek Empire (330 to 440 A.D.), causing laws to be legislated to prevent children from hitting their parents. In the United States of America (US), heavy punishment was imposed on beyond control children during the colonisation of the Bay Colony by the British in the 17th century. According to Regoli and Hewitt (2006), the Stubborn Child Law 1641 provided for a death sentence for children who disobeyed the orders of their parents, in accordance with the teachings of the Book of Deuteronomy (Bible laws). According to the teachings, misbehaviour committed by children should be strictly punished 
since it will raise God's anger at society as a whole. In 1672, the court ordered the separation of beyond control children from their parents by placing them with other individuals who would correct their behaviour. Moreover, Empey (1979) found that punishments such as whipping and hanging in public were carried out to enforce moral values through mechanisms which were intended to embarrass, frighten, and inflict pain on the offenders. Prisons were not built because the colonisers did not believe in rehabilitation or changes in behaviour.

Today, laws governing beyond control behaviour may still be found in some parts of the world including the ASEAN countries such as Malaysia, Brunei, and Singapore; several states of the US; some European countries like the United Kingdom (UK); and several Middle East and African countries including Bahrain, Morocco, and Nigeria (Syed Nong \& Mohd Yusof, 2015). Beyond control behaviour is defined and treated differently in each country. Among the common terms used to indicate such behaviour are "beyond control", "beyond parental control", "beyond the control of any relevant person", "parental disobedience", "incorrigibility", "unruly behaviour", "disruptive behaviour", "difficult behaviour", "out of control", "pre-delinquent", and "ungovernability" (Child Rights International Network, 2009; Kim, 2010). Some of these countries treat beyond control children as victims of abuse or neglect who need care and protection, while other countries manage them as status offenders who may be arrested, detained, and sent to correctional institutions.

Like adults, children are also entitled to the rights and protection guaranteed by international human rights treaties which are developed from the Universal Declaration of Human Rights such as the Convention on the Rights of the Child ("the CRC"), United Nations Guidelines for the Prevention of Juvenile Delinquency ("the Riyadh Guidelines"), and United Nations Standard Minimum Rules for the Administration of Juvenile Justice ("the Beijing Rules"). Generally, the CRC underlines the basic rights of children while the Riyadh Guidelines and Beijing Rules provide guidelines in the administration of justice concerning the rights of children, specifically those who are detained in correctional institutions or prisons. Consequently, this study was carried out to analyse how far the international conventions protect the rights of children who are 
beyond their parents' control and to identify suitable programmes for the implementation of such international principles.

\section{MEANING OF CHILDREN BEYOND CONTROL}

"Children beyond control" means children who are out of their parents' control, notwithstanding the frequent advice given or efforts made by their parents. These children are generally described by the Oxford Dictionaries (n.d.) as those who are inter-alia, unmanageable, unruly, incorrigible, uncontrollable, wild, disobedient, or undisciplined. In legal terms, they are defined as children who have repeatedly failed to follow reasonable commands of their parents, legal guardians, or those exercising custodial control or supervision, whose behaviour results in danger either to the children themselves or other persons (US Legal, n.d.). This definition lays down three characteristics of beyond control behaviour, namely, repetition of misbehaviour, reasonable order by the parents, and the negative effect of such misbehaviour. It corresponds with the view of Theoharis (n.d.) that not all disobedience acts towards parents' orders are "beyond control". According to him, beyond control behaviour must fulfil three characteristics: firstly, it must be committed frequently; secondly, it might harm the welfare, harmony or environmental safety; and thirdly, the parent's orders must be legal. Therefore, a child's refusal to eat vegetables or sleep on time does not constitute beyond control behaviour. Likewise, a misbehaviour is not "beyond control" if the parents force their children to commit crimes or cause them to be exposed to danger. Gough (1971) added that although beyond control children show rebellious acts and put their future in danger, it does not mean that they are infringing any criminal laws.

Beyond control misconduct is considered a "status offence" in several countries including some parts of the US, Japan, and Nigeria, whereby the doer is referred to as a "status offender." Status offence refers to a behaviour which is illegal if committed by children but legal if committed by adults (Britannica Encyclopedia, n.d; US Legal, n.d.). Basically, it is a non-criminal misbehaviour committed by children and therefore must be distinguished from delinquency. This is because "delinquent children" are defined as those committing an unlawful offence, which is punishable if committed by adults, including beating, stealing, and murdering (Black's Law Dictionary, 
n.d.; Britannica Encyclopedia, n.d.; Sherman \& Blitzman, 2011). Although status offences are not crimes, they are prohibited under the law because of the status of the children as minors (Annie E. Casey Foundation, 2019). Some common examples of status offences committed all over the world are: disobedience to parents' or school's orders, running away from home, being absent from school, smoking, consuming alcohol, committing immoral behaviour, and violating curfew laws (Child Rights International Network, 2009; US Legal, n.d.).

Beyond control children all across the world show similar misbehaviour. Nevertheless, the legal concept of beyond control children differs among nations. Syed Nong and Mohd Yusof (2015) found that countries like Japan, Nigeria, and parts of the US treat these children as juvenile offenders and hence, they may be arrested by the police and detained. Meanwhile, England and Wales, and Singapore label these children as "beyond parental control" and treat them as children in need of care and protection instead of children who commit criminal offences. Furthermore, several countries including Indonesia, the Philippines, and some states in the US like New Mexico and New York decriminalise status offenders and introduce community-based rehabilitations to protect the children's best interests. Meanwhile, Malaysia and Singapore appear to share the "parental beyond control application" procedure and order whereby parents are given exclusive power to apply for a beyond control order from the court and detention of their children.

\section{THE CONVENTION ON THE RIGHTS OF THE CHILD}

The CRC identifies that children have different fundamental rights, personality, and capacity from adults and underlines the civil, economic, political, and social rights to fulfil the special needs of children in its 42 articles (Cantwell, 1998). The CRC does not mention beyond control behaviour specifically since it only provides general principles on the rights of all children as a whole. However, principles pertaining to the best interest of the child, the responsibilities of family and the government, and rehabilitation seem to be applicable to children who are beyond control. Article 3 of the CRC states that the best interests of children should be prioritised in all actions and decisions taken concerning them (United Nations Children's 
Fund, n.d.). In this context, Pinheiro (n.d.) and United Nations Human Rights Office of the High Commissioner (n.d.) state that all parties including private and public social welfare institutions, local authorities, courts, and legislative bodies have to consider the effects of their actions on children in order to protect their best interests. Meanwhile, articles 5 and 18 of the CRC outline the responsibilities of parents with the support of the government in bringing up and educating children. While parents have the responsibility to raise their children and should always give their best to the children, the government should respect such responsibility by providing suitable assistance and support to the parents (Pinheiro, n.d.; United Nations Human Rights Office of the High Commissioner, n.d.). The CRC does not take away the responsibility of the parents or give more authority to the government. Instead, it imposes a responsibility on the government to protect and support families in performing their duties as the caregivers of children (United Nations Children's Fund, n.d.). Apart from that, article 9 of the CRC gives children the right not to be separated from their parents except if done for their best interests (Pinheiro, n.d.). Therefore, children should not be sent to welfare institutions unless it is the best resolution for them, and that it is the last resort in rehabilitation.

This study found that the above articles of the CRC constitute a joint responsibility shared between the government and family for the best interests of children. In the context of children who are beyond control, their parents and the government should work together to correct the children's misbehaviour. The parents should not surrender all their responsibilities to government bodies and the government should involve parents in the rehabilitation process of beyond control children. Besides that, detention in correctional institutions should be used as the last resort since children are entitled to be rehabilitated within their family environment first.

Government intervention in child matters is further strengthened by article 20 of the CRC. It provides that the government has the responsibility to intervene if the family environment of the child is not satisfactory (Seymour, 1992). In this situation, the government may provide protection and assistance by offering various forms of alternative care such as foster placement, adoption, and suitable institutional placement if necessary (Champion, 2007). Therefore, in cases of beyond control children, the government has a duty to 
intervene in family matters for the purpose of rehabilitating the children if their parents fail to do so.

Apart from that, the $\mathrm{CRC}$ also underlines the principles concerning children placement in correctional institutions. Articles 37 and 40 of the CRC state that children have a right to rehabilitation that respects them, considers their age, and work towards their reintegration into society (United Nations Human Rights Office of the High Commissioner, n.d.). In addition, article 19 of the CRC specifies the right of children to be protected from any violence. The government should ensure that children are not abused or illtreated by government workers at every procedural stage of the administration of justice, especially in the rehabilitation process and punishment (Pinheiro, n.d.). Nevertheless, placement in institutions should be the last resort or avoided if possible. Alternative care that supports the children's development and that allows them to stay at home is preferable compared to court proceedings and institutional placement. In an appropriate situation, diversion from correctional institutions should be implemented including by way of care and supervision order, probation order, foster care order, and educational and vocational programmes (United Nations Children's Fund, 2010). Application of these CRC principles to children who are beyond control means that they may be placed in correctional institutions only in exceptional circumstances: firstly, correctional institutions are allowed only as a last resort in rehabilitation; secondly, diversion from correctional institutions is encouraged; and thirdly, children who are sent to correctional institutions should be treated with respect and not maltreated, and effectively reintegrated into society.

\section{THE UNITED NATIONS GUIDELINES FOR THE PREVENTION OF JUVENILE DELINQUENCY}

The United Nations Guidelines for the Prevention of Juvenile Delinquency or commonly identified as "The Riyadh Guidelines" provide the guiding principles on delinquency prevention. The guidelines were adopted in 1990 to complement the CRC (United Nations Children's Fund, 2009). Article 10 of the Riyadh Guidelines underlines the importance of legislating preventive policy to assist the success of socialisation and integration of children through family, society, peers, school, and media (Child Rights International 
Network, n.d.). To prevent children from being involved in delinquency, article 5 of the Riyadh Guidelines suggests, among others, that labelling of children as delinquent or pre-delinquent should be avoided because it tends to cause negative behaviour and that community-based services should be developed to avert children from being involved in court proceedings. Besides that, article 5 stresses the vital role of society in preventing children from violating laws by way of helping families to prepare for the care and protection of children (United Nations Children's Fund, 2009).

The Riyadh Guidelines also consists of specific guidelines on status offences. Article 56 recommends that to prevent children from being stigmatised, victimised or criminalised, laws should be legislated to ensure that a status offence is not treated as an offence or punishable if committed by children (Child Rights International Network, n.d.). In this context, this study concludes that beyond control children are a part of status offenders who may be punished for committing status offences and regarded as pre-delinquent children who are at risk of committing crimes in the absence of effective or early treatment. Therefore, prevention is of the utmost importance. Based on the Riyadh Guidelines, children who are beyond control should not be subjected to any negative labelling, and they should be kept away from court proceedings and encouraged to be involved in community-based rehabilitation. One of the best ways to achieve this aim is through legislation. Legal provisions on the behaviour of beyond control children should be abolished to protect the welfare of these children.

\section{THE UNITED NATIONS STANDARD MINIMUM RULES FOR THE ADMINISTRATION OF JUVENILE JUSTICE}

The United Nations Standard Minimum Rules for the Administration of Juvenile Justice or "The Beijing Rules" were approved by the United Nations in 1985 in Beijing, China. The Beijing Rules underlines the international standards on the administration of justice for children. The rules state the minimum standards in dealing with child offenders in ensuring that the principles will be suitable to be applied in different legal systems. Many principles of the Beijing Rules are included in the CRC and applied according to the suitability of the economy, society, and culture of the state party. Articles 2 and 
3 of the Beijing Rules state that the principles are applicable to all children who are involved in court proceedings including criminal offenders, status offenders, and children administered under welfare and care proceedings (United Nations Human Rights Office of the High Commissioner, n.d.).

In general, the Beijing Rules urges each state to establish a special and separate justice system for children's needs, emphasises preventive measures, encourages diversionary programmes, and supports childfriendly procedures. The rules support the protection of children's welfare, minimum intervention by the children's justice system, and reduction of harm caused by such intervention (United Nations Children's Fund, 2009). Article 11 of the Beijing Rules provides that children should be averted from being involved in court proceedings since the courts are the last resort (United Nations Human Rights Office of the High Commissioner, n.d.). As an alternative, articles 18 and 19 of the Beijing Rules recommend that misbehaving children are treated through community-based programmes, supervision, counselling, adoptive care, and other out-of-court measures, while their placement in institutions should be considered as the last resort and ordered for the shortest period (Cantwell, 1998).

This study found that since children who are beyond control are also involved in court proceedings, the Beijing Rules may serve as a guide. Hence, diversionary programmes should be encouraged to minimise intervention by the courts, and institutional placement should be ordered as the last resort by giving priority to family or community-based rehabilitation. This step is important since the involvement of children in court proceedings and their placement in institutions may cause stigmatisation and have a negative influence on them, and may worsen the already poor parent-child relationship caused largely by uncontrolled usage of digital devices nowadays. In fact diversionary programmes are also supported by the CRC and the Riyadh Guidelines, as discussed earlier.

\section{SUGGESTIONS FOR COMPLIANCE WITH INTERNATIONAL CONVENTIONS}

Based on the above discussion, this study suggests diversionary programmes as a suitable means to implement the international 
principles in protecting the best interests of children who are beyond control. In this context, the word "diversion" generally means to settle children's cases outside of court (Roy \& Wong, 2004). Specifically, it changes the direction of a case from court proceedings towards community support to avoid the negative impacts arising from court involvement (Nayagam, 2012). Diversion is a component of restorative justice due to its ability to address children's misbehaviour through community-based rehabilitation rather than punishment. The restorative concept in juvenile justice is supported at the international level by various conventions and agreements such as the CRC and the Riyadh Guidelines as discussed. Among the suitable diversionary programmes identified in this study for the rehabilitation of children beyond control are counselling, family group conference, family and school programme, and mentoring programme.

\section{Group Counselling Programme}

Either group or individual counselling may be conducted. Pre-court group counselling is one of the most suitable methods as it aims to improve the relationship between children and their family members. Group counselling treats children's misbehaviour as a problem that needs to be resolved by all members of the family. Even the parents who have children with the most problematic behaviour will have at least one or two positive elements which can be shared with other families in the group (Rowan, 1976). Group counselling exists in several forms including "parent group counselling," "family counselling," and "parents and children counselling."

"Parent group counselling" consists of several parents who have children with behavioural problems. Among the advantages of this counselling are that it can be conducted even though the social worker has no experience in child development, has never conducted family counselling, has never been married to understand the parent-child relationship, is young, or has no formal training or related certificate (Rowan, 1976). The social worker acts as a coordinator or facilitator without the need to be an experienced or trained person. He does not solve the problems faced by the parents but instead, the sharing of experience between a parent and other parents who have successfully overcome the problem will assist the parents. This counselling is easy and suitable to be implemented for children beyond control 
cases because it supports parental responsibilities. The parents play the role of therapists for themselves and other parents in the group, therefore the parents will not feel depressed or blamed.

Meanwhile, "family counselling" involves members of one family only including the parents, the child with the behavioural problem, and several other family members. In contrast to the above "parent group counselling", this counselling is conducted by a trained and certified counsellor. It focuses on the decision-making process in a family based on the theory that if the relationship and communication in a family can be carried out effectively, then the family itself may overcome any problem that arises (Feeney, 1977). Behavioural problems amongst children can be solved by strengthening their relationships with their family members, especially their parents because close and honest relationships will result in an improved and harmonious life (Abd. Rashid, 2006). This type of counselling does not involve court interference with the child's problem until the counsellor decides that the counselling process was not successful. According to Feeney (1977), the implementation of "family counselling" has drastically reduced the total number of cases which enters the court and has thus replaced the court process. Therefore, children beyond control will feel a sense of belonging and true love from all family members through the strong family bond created.

Alternatively, "parents and children counselling" may be carried out to rehabilitate children who are beyond control. It plays a good role in sharing and solving child-related behavioural problems. This method, which was conducted in Florida on 25 individuals (consisting of 10 children and 15 parents with five sessions per week), was proven to be effective (Rowan, 1976). One of the advantages of this counselling is that it enables the parents and children to get along with each other faster although they have not had any counselling experience before, provided that it is conducted by an experienced counsellor or social worker if the size of the group is large.

\section{Family Group Conference}

Family group conference can be carried out as an effective pre-court diversionary programme for children who are beyond control. It is the main mechanism practised in New Zealand in diverting delinquent children and children under care and protection (including children 
beyond control) from court proceedings. Section 70 of the Children, Young Persons, and Their Families Act 1989 ("the CYPTFA") requires family group conference to be carried out before the application for the declaration that a child needs care and protection can be made. The conference is conducted by a coordinator (who acts as a facilitator and mediator between the family and social worker or police) according to the date, time, and place agreed by the child and family. Among those who may be present at the conference are the child, parent or guardian, coordinator, social worker or police who made the report, the body or organisation which referred the case, the lawyer representing the child, and other parties requested by the family to attend ${ }^{1}$. The conference procedure is determined by the members of the conference themselves while the administrative matters are handled by the responsible government department ${ }^{2}$.

According to section 28 of the CYPTFA, among the functions of the conference are first, to discuss issues relating to the care and protection of the child; second, if the conference views that the child needs care or protection, it will make a decision and draft a suitable plan; and third, to supervise from time to time the decision and plan made and its implementation. The decision and plan will be recorded in writing by the coordinator and is kept at the nearest government department ${ }^{3}$. Any information or admission made during the conference should be kept secret and may not be used as evidence in the court or published ${ }^{4}$.

The implementation of the family group conference in New Zealand in all cases relating to children with a behavioural problem including those beyond control signifies its suitability as an effective rehabilitation process without question. Its inclusion in the legislation enhances the status of diversion as a compulsory step before a child can be brought to court.

\section{Family and School Programme}

The family and school programme is also a suitable method as one of the pre-court diversions. In the US, this programme is known as

Section 22, CYPTFA.

Section 26, CYPTFA.

Section 29, CYPTFA.

Sections 37 and 38, CYPTFA. 
"Families and Schools Together" or FAST and forms an intervention that utilises an available community resource, namely the school, to satisfy the various needs of children with problems and their families. Ellis and Sowers (2001) commented that the programme is effective in the rehabilitation of misbehaving children as well as modification of parenting method because it is based on two sound behaviour theories on human beings, namely Family Stress Theory and Social Ecology Theory. The first theory claims that a depressed human being may influence a family's functioning and children's behaviour. Meanwhile, the second theory claims that since an individual and his/her surroundings are interrelated and in need of each other, changing one's behaviour requires changing his/her surroundings. The family and school programme is a comprehensive technique that has the ability to solve various children behavioural problems and their family issues such as the use of drugs at an early stage, poor family management, family conflict, poor family communication and support, problems at school, negative neighbourhood influence, and peer group problems.

Ellis and Sowers (2001) elaborated further that the involvement of parents in this programme is voluntary, and that the children and their families will be assessed through the Revised Behaviour Problem Checklist before and after the programme. This two-year programme is held at school (may involve the use of the school's meeting room) and consists of eight initial family meeting sessions involving 10 to 15 families in each session, followed by bi-monthly meetings. At school, the children and their families will hold activities that may enhance the family union and identity, improve societal values amongst the families, and develop positive family management and communication skills. Some examples of these activities are taking turns to prepare dinner, singing, playing indoor games like scrabble, and spending time with the children. Upon completion of the programme, the respective family will graduate in a ceremony held at the school that organised the programme. Each member of the family will wear a graduation hat, march into the school hall accompanied by a graduation song, and be conferred with the programme certificate by the school principal. However, the ceremony is only attended by family members and friends.

This study is of the view that the family and school programme is suitable to be implemented on children beyond control for several 
reasons. First, it saves costs since the infrastructures are provided by the school where the particular child is studying. Besides, the types of activities carried out may be varied according to their suitability in a particular community or place. What is more important here is that the participation of parents in the rehabilitation process of their children improves their relationship. The programme benefits the children who are still learning given the support provided by the school authorities in the rehabilitation of its students. Besides, the programme empowers the holistic involvement of the school in protecting its students' welfare, which is not limited to academic learning per se.

\section{Mentoring Programme}

This programme is suggested based on the intervention programme conducted in the US to reduce delinquency and involvement of children in gangsterism, thus improving academic achievement and curbing school truancy. A recent study has found that the programme has a positive impact on children involved in the juvenile justice system (including status offenders) in reducing the recidivism rate in the state of Ohio (Stephanie et al., 2017). The programme relates a child with a behavioural problem (especially a child who lives in a crime-prone neighbourhood and who has failed in his studies) with a responsible adult mentor such as a law enforcer, local businessman, and volunteer who works for a community-based organisation or agency (Belshaw \& Kritsonis, 2007). The programme aims to provide children with positive adult contact to reduce risk factors such as early antisocial behaviour, alienation, and lack of commitment to the school by enhancing protective factors including healthy beliefs, opportunities for involvement, and social reinforcement for appropriate behaviour (Peterson, 2010).

Among the mentor's jobs are to provide support, counselling, supervision and guidance, and career enrichment opportunities; encourage social responsibility development; interact with the child's family; and to provide goals and hope for the future (Belshaw \& Kritsonis, 2007; Peterson, 2010). Examples of the activities which may be carried out are: taking the child along to a moral rehabilitation department meeting, watching a football match, or going to the cinema. This individual interaction is the main step in avoiding crimes from being committed by children in the future 
because it provides the opportunity to build a close and strong relationship between the child with a behavioural problem and a responsible adult.

This study views that the mentoring programme may be conducted to improve beyond control behaviour like school truancy and involvement in gangsterism. Compared to other diversionary programmes, the advantage of this programme is that the child will be guided by a specific mentor selected from members of the community who acts as a role model for him, thus giving more attention to him. However, there are problems faced by the US in implementing this programme. Among the problems as highlighted by Belshaw and Kritsonis (2007) are unrealistic aims of the programme (for example, to measure the repetition of cases occurring instead of the change in children's behaviour); insufficient number of staff and volunteers to be appointed as mentors (since they are tied to their day-to-day jobs); lack of support from members of the community (since it involves naughty or stubborn children); and lack of parents' involvement (the parents did not pay much attention to their child placed under the supervision of the mentor).

\section{CONCLUSION}

The impact of rapid digital development caused by the Fourth Industrial Revolution (IR 4.0) is inevitable on adults including children. However, it may be controlled to protect children from its negative effects. In this context, the international conventions on children's rights offer notable guidelines on the protection of children's best interests including beyond control children who are treated with similar importance as other children who need care and protection, and children who commit crimes.

Children who are beyond control should be kept away from being involved in court proceedings, and institutional placement should be the last resort in the rehabilitation process. Alternatively, family or community-based rehabilitation is the best solution for these children since they have the potential to undergo behavioural change in the future. This method is suitable to treat their misbehaviour, solve their family problems, and prepare them to face the numerous challenges in life including technological breakthroughs in the IR 4.0 era. 


\section{ACKNOWLEDGEMENTS}

This research is funded by the Ministry of Education Malaysia through the Fundamental Research Grant Scheme no. FRGS/1/2019/ SSI10/UNISZA/02/1.

\section{REFERENCES}

Abd. Rashid, A.R. (2006). Menangani perkembangan dan masalah tingkah laku remaja dalam keluarga. In A.R. Abd. Rashid, S. Hussin \& J. Tubah (Eds.), Institusi keluarga menghadapi cabaran alaf baru (pp. 75-88). Kuala Lumpur: Utusan Publications \& Distributors Sdn Bhd.

Annie E. Casey Foundation. (2019). What are status offenses and why do they matter? Retrieved from https://www.aecf.org/ blog/what-are-status-offenses-and-why-do-they-matter/

Belshaw, S. H., \& Kritsonis, W. A. (2007). National implications in juvenile justice: The influence of juvenile mentoring programs on at risk youth. Retrieved from https:/eric. ed.gov/?q=national + implications + in + juvenile + justice\& $\mathrm{id}=$ ED495288

Cantwell, N. (1998, January). Juvenile justice. Innocenti Digest, 3, 1-24. Retrieved from https://www.unicef-irc.org/publications/ pdf/digest3e.pdf

Champion, D. J. (2007). The juvenile justice system: Delinquency, processing and the law (5th ed.). New Jersey: Pearson Education Inc.

Child beyond the control of parents: Law and legal definition. (n.d.). US legal. Retrieved from https://definitions.uslegal.com/c/ child-beyond-the-control-of-parents/

Child Rights International Network. (2009). Age discrimination: Global report on status offences. Child rights international network. Retrieved fromwww.crin.org/en/library/publications/ age-discrimination-global-report-status-offences-2nd-edition

Children in Indonesia: Juvenile justice. (2010). United nations children's fund. Retrieved from http://www.unicef.org/ indonesia/UNICEF_Indonesia_Juvenile_Justice_Fact Sheet_-_June_2010.pdf

Convention on the Rights of the Child. (n.d.). United nations human rights office of the high commissioner. Retrieved from http:// www.ohchr.org/en/professional interest/pages/ crc.aspx 
Delinquency. (n.d.). Britannica encyclopedia. Retrieved from http:// global.britannica.com/EBchecked/topic/156597/delinquency Delinquent child. (n.d.). Black's Law Dictionary. Retrieved from $\mathrm{http}$ ://thelawdictionary. org/delinquent-child/

Duriez, S. A., Sullivan, C., Sullivan, C. J., Manchak, S. M., \& Latessa, E. J. (2017). Mentoring best practices research: Effectiveness of juvenile mentoring programs on recidivism. Office of Justice Programs' National Criminal Justice Reference Service. Retrieved from https://www.ncjrs.gov/ pdffiles1/ojjdp/grants/251378.pdf

Ellis, R. A., \& Sowers, K. M. (2001). Juvenile justice practice: A cross-disciplinary approach to intervention. United States of America: Wadsworth Thomson Learning, Inc.

Empey, L. T. (1979). The progressive legacy and the concept of childhood. In L.T. Empey (Ed.), Juvenile justice: The progressive legacy and current reforms (pp. 3-33). Charlottesville: University Press of Virginia.

Five Key Industry 4.0 Technologies. (2020). OTTO Motors. Retrieved from https://ottomotors.com/blog/5-industry-4-0technologies

Fact sheet: A summary of the rights under the Convention on the Rights of the Child. (n.d.). United Nations Children's Fund. Retrieved from http://www.unicef.org/crc/files/Rights overview.pdf

Feeney, F. (1977). The PINS problem-A "No fault" approach. In L. E. Teitelbaum \& A. R. Gough (Eds.), Beyond control: Status offenders in the Juvenile Court (pp. 249-269). Massachusetts: Ballinger Publishing Company.

Garland, R. (1991, October). Juvenile delinquency in the GraecoRoman world. History Today, 41(10), 12-19. Retrieved from http://ezproxy.um.edu.my:3756/eds/detail/detail? $\mathrm{Vid}=5 \&$ sid=e9fe0a45-f01e-4ffd-901d $\quad 46 \mathrm{~b} 6 \mathrm{aada} 502 \mathrm{f} \% 4$ 0 sessionmgr102\&bdata $=$ JnNpdGU9ZWRzLWxpdmU\% $3 \mathrm{~d} \# \mathrm{AN}=9110210459 \& \mathrm{db}=\mathrm{aph}$

Gough, A. R. (1971, Winter). The beyond-control child and the right to treatment: An exercise in the synthesis of paradox. Saint Louis University Law Journal, 16(2), 182-200. Retrieved from http://heinonlinebackup.com/hol-cgi-bin/get_pdf. cgi?handle=hein.journals/stlulj16\&section $=18$

Kim, J. J. (2010, January). Left behind: The paternalistic treatment of status offenders within the juvenile justice system. Washington 
University Law Review, 87, 843-867. Retrieved from https:// ezproxy.um.edu.my:3833/my/academic/ Default.asp

Matthews, H.T.(2000). Status offenders: Our children's constitutional rights versus what's right for them. Southern University Law Review, 27, 201-214. Retrieved from http://heinonline.org/ HOL/LuceneSearch?terms $=$ status + offenders + our + children $\%$ $27 \mathrm{~s}+$ constitutional + rights $\&$ collection $=$ all \&searchtype $=$ adva nced\&typea $=$ text $\&$ tabfrom $=\&$ submit $=$ Go $\&$ all $=$ true

Nayagam, J. (2012). Strengths and weakness of the protection mechanism and support system for reintegration of children in conflict with the law. The Malaysian Journal on Human Rights, 6, 60-79. Retrieved from http://www.suhakam.org. my/wp-content/uploads/2013/ 11/Binder1.pdf

Out of control. (2018). Oxford Dictionaries. Retrieved from https:// en.oxford dictionaries.com/definition/out_of_control

Peterson, S. B. (2010). Teen/Youth Court programs and mentoring. Office of Juvenile Justice and Delinquency Prevention, Office of Justice Programs, U.S. Department of Justice. Retrieved fromhttps://www.globalyouthjustice.org/wp-content/uploads/ sites/19/2018/01/Teen_Court_and_Mentoring_TA.pdf

Pinheiro, P. S. (n.d.). World report on violence against children. The United Nations Children's Fund (UNICEF). Retrieved from http://www.unicef.org/violence study/ reports.html

Regoli, R. M., \& Hewitt, J. D. (2006). Delinquency in society (6th ed.). New York: Mc Graw Hill.

Rowan, J. R. (1976). Parens patriae is wrong (Parent supporter is right). Juvenile Justice, 27, 17-23 Retrieved from http://heinonline.org/HOL/Page?handle=hein.journals/ juvfc $27 \&$ div $=17 \&$ start page $=17 \&$ collection=journals\&set as cursor $=10 \&$ men $\mathrm{tab}=$ srch results

Roy, N., \& Wong, M. (2004). Juvenile justice: Modern concepts of working with children in conflict with the law. Child Rights Information Network. Retrieved from https://www.crin.org/ en/library/publications/juvenile-justice-modern-conceptsworking-children-conflict-law

Schwab, K. (2016, January 14). The fourth industrial revolution: What it means and how to respond. World Economic Forum. Retrieved from https://www.weforum.org/ agenda/2016/ 01/ the-fourth-industrial-revolution

Seymour, J. (1992). An "uncontrollable" child: A case study in children's and parents' rights. In P. Alston, S. Parker \& J. 
Seymour (Eds.), Children, rights, and the law (pp. 98-118). Oxford: Clarendon Press.

Sherman, F. T., \& Blitzman, J. (2011). Children's rights and relationships: A legal framework. In F. T. Sherman \& F. H. Jacobs (Eds.), Juvenile justice: Advancing research, policy and practice (pp. 68-91). New Jersey: John Wiley \& Sons. Inc.

Status offense. (n.d.). US Legal. Retrieved from http://definitions. uslegal. com/s/status-offense-action-juvenile-law/

Syed Nong, S. N. A., \& Mohd Yusuf, J. Z. (2015). The legal concept of children beyond control: A global perspective. Pertanika Journal of Social Sciences \& Humanities, 23(S), 63-74.

The fourth industrial revolution and what it means for students like you. (2018, May 2). StudyMalaysia.com. Retrieved from https:/www.studymalaysia.com/education/top-stories/ thefourth-industrial-revolution

The state of the world's children 2017: Children in a digital world. (2017, December). United Nations Children's Fund(UNICEF). Retrieved from https://www.unicef.org/ publications/files/ SOWC_2017_ENG_WEB.pdf

Theoharis, M. (n.d.). Incorrigibility: Juvenile laws. Defense Lawyer. Retrieved from http://www.criminal defense lawyer.com/ crime-penalties/juvenile/incorrigibility.htm

United Nations Guidelines for the Prevention of Juvenile Delinquency ("Riyadh Guidelines"). (n.d.). Child Rights International Network. Retrieved from https://www. crin.org/en/docs/resources/ publications/hrbap/IHCRC/ UnitedNationsGuidelinesforthePrevention ofJuvenile Delinquency.pdf

United Nations Standard Minimum Rules for the Administration of Juvenile Justice ("The Beijing Rules"). (n.d.). United Nations Human Rights Office of the High Commissioner. Retrieved from http://www.ohchr.org/Documents/ProfessionalInterest/ beijingrules. pdf

Working with children in conflict with the law. (2009). United Nations Children's Fund. Retrieved from http://www.unicef. org/easterncaribbean/Working_with_children_in__ conflict _with_the _law.pdf 